\title{
The Relationship of Parent's knowledge about Cervical Cancer with The Giving of The HPV Vaccination to their Daughter
}

\author{
Nabila Syauqhi Wijanarko ${ }^{1}$, Pungky Mulawardhana ${ }^{2 *}$, and Sulistiawati ${ }^{1,3}$ \\ ${ }^{1}$ Department of Midwifery Education, Faculty of Medicine University Airlangga 60132, Surabaya, East Java, Indonesia \\ ${ }^{2}$ Department of Obsterics and Gynecology, Faculty of Medicine University Airlangga 60132, Surabaya, East Java, Indonesia \\ ${ }^{3}$ Department of Public Health and Preventive Medicine, Faculty of Medicine University Airlangga 60132, Surabaya, East Java, \\ Indonesia \\ Corresponding Author : pungky.mulawardhana@gmail.com
}

\begin{abstract}
Background: The incidence of cervical cancer in Indonesia ranks second with $10.7 \%$ and the death rate ranks third with $10.3 \%$ recorded by Globocan in 2018. The HPV virus or Human Papilloma Virus is known as the cause of cervical cancer, especially on viruses types 16 and 18 . The Indonesian government is currently planning to add the HPV vaccine to the national immunization program. For Surabaya, HPV vaccination has been running since 2015 in several schools. Methods: This study used an observational analytic method with a cross-sectional approach. The number of sample is as many as 74 respondents, with the sampling technique that is total sampling with the determination of inclusion and exclusion criteria. The independent variable is the knowledge of parents about cervical cancer. The dependent variable is the act of giving vaccinations to students. The data taken is primary data in August 2021. Data analysis uses univariate and bivariate analysis. This study used the chi square statistical test $(\mathrm{p}<0.05)$. Results: The results of this study indicate that $41.9 \%$ of respondents who have good knowledge, most of them give HPV vaccination and $10.8 \%$ of respondents who have less knowledge, then a small proportion who give HPV vaccination. The results of the chi square test showed a relationship between knowledge and the provision of HPV vaccination $(p=0.01)$. Conclusion: It is better to conduct socialization first before vaccinating against HPV for mothers and daughters considering the urgency of this vaccination is different from other vaccines.
\end{abstract}

Keywords: Knowledge; Cervical Cancer; HPV Vaccine; SDGs

\section{Introduction}

Cervical cancer is a disease characterized by the spread of abnormal cells and uncontrolled cell growth. Cervical cancer ranks first in developing countries and the second most common cancer in women in the world (Ge'e et al., 2021) (Herlana et al., 2017; Nurlelawati et al., 2018). The HPV virus or Human Papilloma Virus is known as the cause of cervical cancer, especially in viruses types 16 and 18. (Health, Prevention and National, 2019).

The incidence of cervical cancer in Indonesia ranks second with $10.7 \%$ and the death rate ranks third with 10.3\% recorded by Global Burden Cancer (Globocan) in 2018 (Yulia, 2019). Meanwhile, the number of cervical cancer cases in 2017 in East Java reached 229.084 patients (Ahmad Fahrur Rozi, 2018). With these conditions, the Indonesian government is currently planning to add the HPV vaccine to the national immunization program. The HPV immunization program through the School 
Children's Immunization Month (BIAS) program begins with the provision of immunizations in pilot locations that have a high prevalence of cervical cancer.

For Surabaya itself, HPV vaccination has been running in several schools since 2015 which started in the West Surabaya area. Then develop it in all health centers in Surabaya, one of which has received this HPV vaccine program is SDN Ngagel Rejo III and SDN Sidosermo I Surabaya. From this explanation, it is necessary to have this study with the aim of analyzing the relationship between parental knowledge about cervical cancer and giving HPV vaccination to students at SDN Ngagel Rejo III and SDN Sidosermo I Surabaya.

\section{Method}

This type of research is quantitative research, namely observational analytic with a cross sectional approach. The population and sample in this study were all parents of grade 5 and 6 students at SDN Ngagel Rejo III and SDN Sidosermo I Surabaya in August 2021, totaling 74 respondents using the data collection technique, namely total sampling. The independent variable in this study was the knowledge of parents about cervical cancer and the dependent variable was the act of giving HPV vaccination to female students for cervical cancer prevention.

\section{Result}

Respondents in this research amounted to 74 respondents. The following table describes the general description of the characteristics of mothers who were respondents in this study:

Table 1. Characteristics and general data of respondents at SDN Ngagel Rejo III and SDN Sidosermo I Surabaya in August 2021.

\begin{tabular}{cccc}
\hline Characteristics & & $\mathbf{N}$ & $\mathbf{( \% )}$ \\
\hline \multirow{3}{*}{ Age } & $15-20$ & 23 & 31.1 \\
& $21-25$ & 37 & 50.0 \\
& $26-30$ & 8 & 10.8 \\
& $>30$ & 6 & 8.1 \\
\hline \multirow{2}{*}{ Education } & Primary School & 9 & 12.2 \\
& Junior High School & 13 & 17.6 \\
& Senior High School & 41 & 55.4 \\
& College & 11 & 14.9 \\
\hline \multirow{2}{*}{ Profession } & Housewife & 44 & 59.5 \\
& Seller & 10 & 13.5 \\
& Entrepreneur & 17 & 23.0 \\
& Civil Servant / Soldier & 3 & 4.1
\end{tabular}


Table 2. Frequency distribution of respondents' knowledge at SDN Ngagel Rejo III and SDN Sidosermo I Surabaya in August 2021.

\begin{tabular}{ccc}
\hline Education & $\mathbf{N}$ & \% \\
\hline Good & 34 & 45.9 \\
Enough & 29 & 39.2 \\
Less & 11 & 14.9 \\
\hline
\end{tabular}

Table 3. Distribution of the frequency of respondent actions at SDN Ngagel Rejo III and SDN Sidosermo I Surabaya in August 2021.

\begin{tabular}{ccc}
\hline Action & N & \% \\
\hline Positive & 59 & 79.7 \\
Negative & 15 & 20.3 \\
\hline
\end{tabular}

Table 4. The relationship between parental knowledge about cervical cancer and the provision of HPV vaccination to female students at SDN Ngagel Rejo III and SDN Sidosermo I Surabaya in August 2021.

\begin{tabular}{lccccc}
\hline & Knowledge & \multicolumn{2}{c}{ Action } & \\
\hline & \multicolumn{2}{c}{ Potsitive } & \multicolumn{2}{c}{ Negative } & Chi-square Test \\
& N & $\%$ & N & $\%$ & P value \\
Good & 31 & 41.9 & 3 & 4.0 & \\
Enough & 25 & 33.8 & 4 & 5.4 & 0.001 \\
Less & 3 & 4.1 & 8 & 10.8 & \\
\hline
\end{tabular}

\section{Discussion}

\subsection{Respondent Knowledge}

Respondents' knowledge was measured through interviews by giving 10 questions about cervical cancer in general. From the results of interviews conducted with respondents, the results in Table 2 show that most of the $34(45.9 \%)$ respondents in SDN Ngagel Rejo III and SDN Sidosermo I Surabaya have good knowledge. 
Knowledge is a result of knowing, occurring after someone has sensed an object. Sensing occurs through the five human senses, namely the senses of sight, hearing, smell, taste and touch (Bolisani and Bratianu, 2018). This is in line with the opinion that knowledge and action are interesting relationships, as has been shown, there are conscious and unconscious influences and especially the logical not causal, relationship between knowledge environment, values environment and ecological behavior (good intentions as observed behavior) (Funke, 2017).

In table 1, the respondent's age variable at marriage can be seen that most are aged 21-25 years, namely $37(50.0 \%)$ which means that one's maturity and strength in thinking has increased so that it can provide broad knowledge. Knowledge can occur from several factors such as age. Increasing age will increase a person's maturity and strength in thinking, This is measured in terms of public trust of people who are more mature and more confident than people with maturity who are not yet high enough. This is because it is a result of the experience of the soul (Nursalam, 2011).

While the education variable explained that most of the 41 (55.4\%) respondents had education at the high school level. In this study, most of the respondents had a history of high school education, which means that the level of education is high, so they have a lot of knowledge. And there is also a factor from work, which is a need that must be done especially to support daily life about oneself or one's family (According to Thomas 2007, in Nursalam 2011). Then the factor of educational history, the higher the level of human education, the more knowledge that human will have. Likewise, with the opposite, the less a person's education is, the more hampered the development of one's attitude towards the newly introduced values will be (Nursalam, 2011). The work variable explains that most of the $44(59.5 \%)$ respondents are housewives. Work is not only a source of pleasure, but more work can also be a way to substitute a source of information for something new.

\subsection{HPV Vaccination Measures}

The act of vaccinating HPV is seen through the parents' decision to give permission to vaccinate their daughters, considering that the students do not yet have the right to make their own decisions. In this study, the status of HPV vaccination was known from the results of interviews using questionnaires to respondents. Table 3 explains that most of the 59 (79.7\%) respondents have positive actions as an effort to prevent cervical cancer. 
All behavior can be explained as an attempt by the individual to bring about some state - either to effect a change from one state to another, or to maintain a current one (Bergner, 2011). Practice or action is a real implementation on the basis of existing theory or the implementation of work. Health practice or health behavior is when a person knows a health stimulus or object, then conducts an assessment or opinion on what is known, implements or practices what is known or addressed (Candraningsih in Novitasari, 2019).

The health actions or behaviors discussed in this study are based on the cervical cancer prevention efforts carried out by the respondents, namely preventing cervical cancer by giving their daughter the HPV vaccination. This is influenced by the knowledge of cervical cancer that respondents already have.

4.3 The Relationship of Knowledge of Cervical Cancer with the Provision of HPV Vaccination Theoretically, knowledge and action is an interesting relationship. As has been shown, there are conscious and unconscious influences and especially on logical, not causal, which analyzes the relationship between knowledge environment, values environment and ecological behavior (good intentions as observed behavior). Finally, concludes on the basis of the structural equation model that only $40 \%$ of the variation in actions requires attributes for knowledge and values, but the action explains $75 \%$ of the variation in behavioral differences. From this point of view, it can be concluded that something will not happen without knowledge, but humans can act at least - on a basic level (Funke, 2017).

Knowledge becomes an indirect influence of perception on one's decision making. Based on the results of the tests carried out, it can be concluded that knowledge which is an indirect influence shows significant results in influencing a person's perception in making decisions about decision making with a $\mathrm{P}$ value of 0.017 . And also in the study it was said that this knowledge factor became the dominant factor influencing decisions (Warsini and Septiawan, 2021). This theory strengthens the results of research which says that there is a relationship between parental knowledge about cervical cancer and the provision of HPV vaccination to students at SDN Ngagel Rejo III and SDN Sidosermo I Surabaya. 
This explanation is in line with the results of this study in Table 4 which says that parents with good, sufficient and less knowledge are dominated by parents who give HPV vaccination to their daughters of 59 (79.8\%) respondents but a small proportion of respondents were found who did not give HPV vaccination to female students. As many as 15 (20.2\%) respondents mostly due to fear, do not want and do not know the information. From these problems, researchers can suggest a solution, namely by providing socialization prior to HPV vaccination to the guardians of students and/or students so that information can be conveyed properly.

\section{Conclusion}

Based on the results of the analysis and discussion discussed above, regarding the relationship between parental knowledge about cervical cancer and the provision of HPV vaccination to students at SDN Ngagel Rejo III and SDN Sidosermo I Surabaya, the following conclusions can be drawn:

1. Most parents have good knowledge about cervical cancer and a few parents have less knowledge about cervical cancer.

2. Most parents provide HPV vaccination for their students and a small proportion do not provide HPV vaccination for their students.

3. From the results obtained, there is a significant relationship between knowledge and the action of HPV vaccination.

\section{Acknowledgements}

The author expresses his deepest gratitude to the principals of SDN Ngagel Rejo III and SDN Sidosermo I Surabaya who have given permission to conduct research in these places, the supervisors who have guided during the research and preparation of this manuscript and do not forget to thank the researchers for their parents. And fellow researchers who have provided support for researchers to complete this research properly.

\section{References}

Ahmad Fahrur Rozi, N. (2018) 'Karakteristik Pasien Kanker Serviks Di Instalasi Rawat Inap Rsud. Dr. Soetomo Surabaya Periode 1 Januari 2017 - 31 Desember 2017'. Available at: http://lib.unair.ac.id (Accessed: 16 November 2021).

Altmann, T. K. (2008) 'Attitude: a concept analysis.', Nursing forum, pp. 144-150. doi: 10.1111/j.17446198.2008.00106.x 
Bergner, R. M. (2011) 'What is behavior? And so what?', New Ideas in Psychology, 29(2), pp. 147-155. doi: 10.1016/j.newideapsych.2010.08.001.

Bohner, G. and Dickel, N. (2010) 'Attitudes and Attitude Change'. doi: 10.1146/annurev.psych.121208.131609.

Bolisani, E. and Bratianu, C. (2018) 'The Elusive Definition of Knowledge', in Knowledge Management and Organizational Learning. Springer Nature, pp. 1-22. doi: 10.1007/978-3-319-60657-6_1.

Cancer, O. (no date) Cervical cancer - Symptoms and causes - Mayo Clinic, American cancer Society. Available at: https://www.mayoclinic.org/diseases-conditions/cervical-cancer/symptoms-causes/syc20352501 (Accessed: 17 May 2021).

Cartmell, K. B. et al. (2018) 'Barriers, facilitators, and potential strategies for increasing HPV vaccination: A statewide assessment to inform action', Papillomavirus Research, 5, pp. 21-31. doi: 10.1016/j.pvr.2017.11.003.

Cheng, L., Wang, Y. and Du, J. (2020) 'Human papillomavirus vaccines: An updated review', Vaccines. MDPI AG, pp. 1-15. doi: 10.3390/vaccines8030391.

Curry, S. J. et al. (2018) 'Screening for cervical cancer us preventive services task force recommendation statement', JAMA - Journal of the American Medical Association, 320(7), pp. 674-686. doi: 10.1001/jama.2018.10897.

Dumilah Ayuningtyas, N. N. D. S. (2018) 'View of Indonesia's readiness to implement the HPV vaccine mandatory for school age', $9 . \quad$ Available at: https://ejournal2.litbang.kemkes.go.id/index.php/hsji/article/view/910/669 (Accessed: 31 May 2021).

Ekowati, D. et al. (2017) Hubungan Pengetahuan Dengan Persepsi Mahasiswi Dalam Penerimaan Vaksinasi Hpv Sebagai Upaya Pencegahan Kanker Serviks. Available at: http://ejournal3.undip.ac.id/index.php/jkm (Accessed: 24 March 2021).

Firdausy, V. G. and Ghozali, G. (2018) 'Hubungan antara Pengetahuan dan Sikap dengan Perilaku Pencegahan Kanker Serviks Melalui Vaksinasi HPV (Human Papilloma Virus) pada Wanita di Wilayah Kerja PUSKESMAS Kampung Baru Ulu Balikpapan'. Available at: https://dspace.umkt.ac.id//handle/463.2017/1835 (Accessed: 16 November 2021).

Fontham, E. T. H. et al. (2020) 'Cervical cancer screening for individuals at average risk: 2020 guideline update from the American Cancer Society', CA: A Cancer Journal for Clinicians, 70(5), pp. 321346. doi: 10.3322/caac. 21628 .

Funke, J. (2017) 'How Much Knowledge Is Necessary for Action?', in, pp. 99-111. doi: 10.1007/978-3-31944588-5 6. 
Ge'e, M. E. et al. (2021) 'Hubungan antara Karakteristik, Pengetahuan dengan Kejadian Kanker Serviks', Jurnal Keperawatan Silampari, 4(2), pp. 397-404. doi: 10.31539/jks.v4i2.1668.

Herzig, A., Lorini, E. and Troquard, N. (2018) 'Action Theories', in, pp. 591-607. doi: 10.1007/978-3-31977434-3_33.

Imunization Safety Office, D. of H. Q. P. N. C. for E. and Z. I. D. (2019) HPV Vaccination is Safe and Effective | CDC, National Center for Emerhing and Zoonotic Infectious Diseases. Available at: https://www.cdc.gov/hpv/parents/vaccinesafety.html (Accessed: 18 May 2021).

Jirwanto, H. (2021a) 'Hubungan Tingkat Pengetahuan Kanker Serviks Dengan Minat Untuk Vaksinasi HPV Pada MahasiswiI Fakultas Kedokteran Universitas HKBP Nommensen Medan’, Nommensen Journal of Medicine, 6(2), pp. 58-61. doi: 10.36655/njm.v6i2.492.

Jirwanto, H. (2021b) 'Hubungan Tingkat Pengetahuan Kanker Serviks Dengan Minat Untuk Vaksinasi HPV Pada Mahasiswil Fakultas Kedokteran Universitas HKBP Nommensen Medan', Nommensen Journal of Medicine, 6(2), pp. 58-61. doi: 10.36655/njm.v6i2.492.

Kesehatan, K., Penanggulangan, K. and Nasional, K. (2019) Kanker Serviks.

Kristiyanti, N. (2021) Hubungan Pengetahuan Remaa Putri Tentang Kanker Serviks Dengan Motivasi Untuk Melakukan Vaksinasi Human Papilloma Virus (HPV) Di SMP Negeri 1 Tabanan.

Kumar Mohajan, H. (2016) Munich Personal RePEc Archive Knowledge is an Essential Element at Present World Knowledge is an Essential Element at Present World.

Novitasari, F. (2019) 'Hubungan pengetahuan tentang kanker serviks dengan tindakan vaksinasi hpv pada mahasiswi program studi kebidanan fakultas kedokteran universitas airlangga'.

Pengetahuan, H. et al. (2018) 'Hubungan pengetahuan kanker serviks pada remaja putri dengan sikap dan tindakan pencegahan kanker serviks di smk kawung 2 surabaya'.

Ramadhiani, A. A. (2020) 'Hubungan Tingkat Pengetahuan Ibu Postpartum Dengan Mobilisasi Dini Di Puskesmas Blooto Kota Mojokerto.'

Safaeian, M. et al. (2018) 'Durability of Protection Afforded by Fewer Doses of the HPV16/18 Vaccine: The CVT Trial', Journal of the National Cancer Institute, 110(2). doi: 10.1093/jnci/djx158.

Sri Dewi Handayani *, SrDyah Noviawati Setya Arum and Nanik Setiyawa (2018) 'Faktor-Faktor Yang Mempengaruhi Perilaku Pemeriksaan Iva Pada Wanita Usia Subur Di Desa Penyak Kecamatan Koba Kabupaten Bangka Tengah Tahun 2017'. Available at: http://poltekkesjogja.ac.id (Accessed: 17 May 2021).

The American Cancer Society medical and editorial content, T. (no date) 'Cervical Cancer Early Detection, Diagnosis, and Staging'. doi: 10.1097/LGT.0000000000000528. 
Warsini, W. and Septiawan, C. (2021) 'Faktor - Faktor yang Berpengaruh terhadap Pengambilan Keputusan Vaksinasi HPV', Jurnal Ilmiah Kebidanan Indonesia, 11(02), pp. 97-107. doi: 10.33221/JIKI.V11I02.918.

Yulia, D. (2019) 'Non Communicable disease and prevention: Melalui Pemeriksaan IVA Tes di Kota Jambi Tahun 2015-2018', UGM Public Health Symposium, p. 7659.

\section{Nomenclature}

A radius of

B position of 
C further nomenclature continues down the page inside the text box

\subsection{Structure}

For this Procedia the files must be in MS Word format only and should be formatted for direct printing. Figures and tables should be embedded and not supplied separately. Please make sure that you use as much as possible normal fonts in your documents. Special fonts, such as fonts used in the Far East (Japanese, Chinese, Korean, etc.) may cause problems during processing. To avoid unnecessary errors you are strongly advised to use the 'spellchecker' function of MS Word. Follow this order when typing manuscripts: Title, Authors, Affiliations, Abstract, Keywords, Main text (including figures and tables), Acknowledgements, References, Appendix. Collate acknowledgements in a separate section at the end of the article and do not include them on the title page, as a footnote to the title or otherwise.

Bulleted lists may be included and should look like this:

- First point

- Second point

- And so on

Ensure that you return to the 'Els-body-text' style, the style that you will mainly be using for large blocks of text, when you have completed your bulleted list.

Please do not alter the formatting and style layouts which have been set up in this template document. As indicated in the template, papers should be prepared in single column format suitable for direct printing onto A4 paper (192mm x $262 \mathrm{~mm})$. Do not number pages on the front, as page numbers will be added separately for the preprints and the Proceedings. Leave a line clear between paragraphs. All the required style templates are provided in this document with the appropriate name supplied, e.g. choose 1. Els1st-order-head for your first order heading text, els-abstract-text for the abstract text etc.

\subsection{Tables}

All tables should be numbered with Arabic numerals. Headings should be placed above tables, left justified. Leave one line space between the heading and the table. Only horizontal lines should be used within a table, to distinguish the column headings from the body of the table, and immediately above and below the table. Tables must be embedded into the text and not supplied separately. Below is an example which authors may find useful.

Table 1. An example of a table

\begin{tabular}{lll}
\hline An example of a column heading & Column A (t) & Column B (T) \\
\hline And an entry & 1 & 2 \\
And another entry & 3 & 4 \\
And another entry & 5 & 6 \\
\hline
\end{tabular}

\subsection{Construction of references}

References should be added at the end of the paper, and its corresponding citation will be added in the order of their appearance in the text. Authors should ensure that every reference in the text appears in the list of references and vice versa. Indicate references by Clark et al., 1962 or Deal and Grove, 2009 or Fachinger, 2006 in the text. The actual authors can be referred to, but the reference citation(s) must always be given. 
Some examples of how your references should be listed are given at the end of this template in the 'References' section, which will allow you to assemble your reference list according to the correct format and font size.

\subsection{Section headings}

Section headings should be left justified, with the first letter capitalized and numbered consecutively, starting with the Introduction. Sub-section headings should be in capital and lower-case italic letters, numbered 1.1, 1.2, etc, and left justified, with second and subsequent lines indented. You may need to insert a page break to keep a heading with its text.

\subsection{General guidelines for the preparation of your text}

Avoid hyphenation at the end of a line. Symbols denoting vectors and matrices should be indicated in bold type. Scalar variable names should normally be expressed using italics. Weights and measures should be expressed in SI units. Please title your files in this order conferenceacrynom_authorslastname.pdf

\subsection{Footnotes}

Footnotes should be avoided if possible. Necessary footnotes should be denoted in the text by consecutive superscript letters. The footnotes should be typed single spaced, and in smaller type size (8pt), at the foot of the page in which they are mentioned, and separated from the main text by a short line extending at the foot of the column. The 'Els-footnote' style is available in this template for the text of the footnote.

\section{Author Artwork}

All figures should be numbered with Arabic numerals $(1,2, \ldots \mathrm{n})$. All photographs, schemas, graphs and diagrams are to be referred to as figures. Line drawings should be good quality scans or true electronic output. Low-quality scans are not acceptable. Figures must be embedded into the text and not supplied separately. Lettering and symbols should be clearly defined either in the caption or in a legend provided as part of the figure. Figures should be placed at the top or bottom of a page wherever possible, as close as possible to the first reference to them in the paper.

The figure number and caption should be typed below the illustration in 8pt and left justified. For more guidelines and information to help you submit high quality artwork please visit: http://ijrp.org/page/instruction. Artwork has no text along the side of it in the main body of the text. However, if two images fit next to each other, these may be placed next to each other to save space, see Fig 1. They must be numbered consecutively, all figures, and all tables respectively.

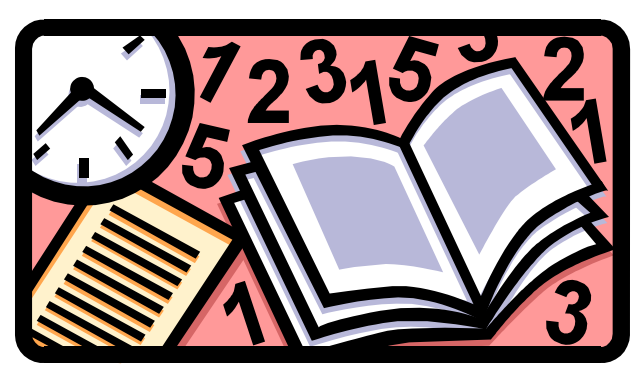


Fig. 1. (a) first picture; (b) second picture

Equations and formulae should be typed and numbered consecutively with Arabic numerals in parentheses on the right hand side of the page (if referred to explicitly in the text),

$$
\rho=\frac{\overrightarrow{\mathrm{E}}}{\mathrm{J}_{\mathrm{C}}(\mathrm{T}=\text { const. }) \cdot\left(\mathrm{P} \cdot\left(\frac{\overrightarrow{\mathrm{E}}}{\mathrm{E}_{\mathrm{C}}}\right)^{\mathrm{m}}+(1-\mathrm{P})\right)}
$$

They should also be separated from the surrounding text by one space.

\section{Acknowledgements}

These and the Reference headings are in bold but have no numbers. Text below continues as normal.

\section{References}

Clark, T., Woodley, R., De Halas, D., 1962. Gas-Graphite Systems, in “Nuclear Graphite” R. Nightingale, Editor. Academic Press, New York, p. 387.

Deal, B., Grove, A., 1965. General Relationship for the Thermal Oxidation of Silicon, Journal of Applied Physics 36 , p. 3770.

Deep-Burn Project: Annual Report for 2009, Idaho National Laboratory, Sept. 2009.

Fachinger, J., den Exter, M., Grambow, B., Holgerson, S., Landesmann, C., Titov, M., Podruhzina, T., 2004."Behavior of spent HTR fuel elements in aquatic phases of repository host rock formations," $2^{\text {nd }}$ International Topical Meeting on High Temperature Reactor Technology. Beijing, China, paper \#B08.

Fachinger, J., 2006. Behavior of HTR Fuel Elements in Aquatic Phases of Repository Host Rock Formations. Nuclear Engineering \& Design 236, p. 54.

\section{Appendix A. An example appendix}

Authors including an appendix section should do so after References section. Multiple appendices should all have headings in the style used above. They will automatically be ordered A, B, C etc.

A.1. Example of a sub-heading within an appendix

There is also the option to include a subheading within the Appendix if you wish. 